保健物理, 14, 89 93 (1979)

\title{
般 論文
}

\section{硝酸セルロースフィルムにおける放電計数特性}

\author{
丹羽健夫*1, 古賀妙子*1, 森嶋彌重 ${ }^{* 1}$, 河合 廣*1, 西脇 安*1
}

(1978 年 6 月 5 日受理)

(1978 年 10 月 2 日再受理)

\author{
Spark Counting Characteristics of Etched Alpha-particle Tracks on \\ Cellulose Nitrate Films
}

Takeo Niwa, ${ }^{* 1}$ Taeko KogA, ${ }^{* 1}$ Hiroshige Morishima, ${ }^{* 1}$
Hiroshi KAWAI ${ }^{* 1}$ and Yasushi NishIWAKI

Basic spark counting characteristics of cellulose nitrate films $13 \mu \mathrm{m}$ thick stripped off from the polyester bases of LR-115 Type II and LR-115 Type II Stripping made by KODAK-PATHÉ in France were investigated. Detector films irradiated with $\alpha$-ray were etched with $\mathrm{NaOH}$ solution, sandwiched between copper and aluminized sheet electrodes, and the number of sparks was counted with a scaler. Results obtained were as follows:

1) Optimum etching condition was $26 \% \mathrm{NaOH}$ solution at $50^{\circ} \mathrm{C}$ and etching time was $140 \mathrm{~min}$.

2) Sparking voltages were $600 \mathrm{~V}$ for punching and $425 \mathrm{~V}$ for counting.

3) Optimum thickness of polycarbonate sheet for a moderator was $20 \mu \mathrm{m}$.

4) The relation between irradiation time and number of counts was linear up to about $1,000 / \mathrm{cm}^{2}$.

LR-115 Type II Stripping B, which was sticked with thin $\mathrm{LiBO}_{2}$ layer on one side of the film, was also examined. It was irradiated with neutron produced from the reactor of Kinki University. Neutron fluence was estimated from spark counting of $\alpha$-tracks produced by $(\mathrm{n}, \alpha)$ reaction. The relation between spark counts and neutron fluence was linear between $2 \times 10^{8}$ and $4 \times 10^{9} \mathrm{n} / \mathrm{cm}^{2}$.

KEY WORDS: dielectric track detectors, nitro-celluloses, personnel dosimetry, spark counters.

\section{I 序論}

放電計数法は CROSS および TOMMASINO により開 発された1)。 $\alpha$ 線および陽子飛跡の放電計数は, 検出器 に使用できるセルロースがポリカーボネートに比べて化 学的, 機械的に弱く, 取扱いに細かい注意が必要であり, 研究例も数が少ない。 $\alpha$ 線については, 1969 年, BECKER 等が自作した硝酸セルロースフィルムで成功し

*1 近畿大学原子力研究所; 東大阪市小若江 3-4-1（价77) Atomic Energy Research Institute of Kinki University, 3-4-1 Kowakae, Higashi-osaka City, Osaka, Japan 577.
て特り2)，その後，1974 年に同じく BECKER 等がフラ ンス KODAK-PATHÉ 社の硝酸セルロースフィルム $\mathrm{LR}-115,8 \mu \mathrm{m}$ 厚を用いて $(\mathrm{n}, \mathrm{p})$ 反応による反跳陽子 の飛跡について実験を行なった ${ }^{3 \sim 4)}$ 。をた 1975 年 HAHN 等は ${ }^{6} \mathrm{Li}(\mathrm{n}, \alpha){ }^{3} \mathrm{He}$ の $\alpha$ 線を適当な可塑剂を入れて製作 した硝酸セルロースフィルムを用いて測定しだ5。かが 国では, 1978 年鶴田等が ${ }^{10} \mathrm{~B}(\mathrm{n}, \alpha){ }^{7} \mathrm{Li}$ の $\alpha$ 線をアセト ンと酢酸イソアミルを溶媒とし, 硝酸セルロース, 樟脳 およびオルトカルボランを溶質とする溶液から作ったフ ィルムで放電計数に成功している ${ }^{6)}$ 。我々も 1973 年以 来, $\alpha$ 線の放電計数の研究を行なってきた 
1）バイエル社製酢酸セルロース（TRIAFOL，30 $\mu \mathrm{m}$ 厚)，2）TRIAFOL の厚みを減らすため溶解して薄く引 き延ばす，3）国産の硝酸セルロ一ス粉末を溶解して薄 く引き延ばす, 4) KODAK-PATHÉ 社製 LR-115 Type II 硝酸セルロースフィルム $(9 \times 12 \mathrm{~cm}, 13 \mu \mathrm{m}$ 厚 $)$ を ベースからはがすなど種々の方法を試みたが，1）につ いては放電計数には厚すぎ，2，3）についてはしわが できたり，機械的に弱いなど欠点があり，研究室におけ る小規模な製作では毎回均一で一定の厚みのフィルムを 得ることは困難であるので, 量産され市販されている LR-115を使用することにした。すなわち, LR-115 Type II フィルムをベースからはがしたもの，LR-115 Type II Stripping 特よび Stripping B の 3 種のフィ ルムについて, ベースからのはがし方, エッチングの仕 方による放電計数の諸特性を比較検討した。

\section{II 実験}

1. 飛跡検出用フィルム

a) LR-115 Type II：このフィルムは不活性ポリエ ステルベース約 $100 \mu \mathrm{m}$ 厚に赤色の $13 \mu \mathrm{m}$ 厚の硝酸セ ルロースフィルムをはりつけたもの $(9 \mathrm{~cm} \times 12 \mathrm{~cm})$ で ある。陽子， $\alpha$ 粒子など荷電粒子照射後エッチングして から顕微鏡下で飛跡数を数えるとき, 赤背景からエッチ ピットの所だけ白く抜け, 数えやすい特徵がある。我々 はこれを放電計数に使らため，ポリエステルベースより 硝酸セルロースフィルムのはがし方についていろいろ試 みた結果, 熱湯を用いれば容易にはがれ, 良好な特性が 得られることがわかった。

b ) LR-115 Type II Stripping および LR-115 Type II Stripping B $(20 \mathrm{~cm} \times 60 \mathrm{~cm})$ : これはポリエステル ベースから硝酸セルロースフィルムを容易にはがすこと ができるタイプで，大きさを除き，使用目的，物理的性 質特よび厚みは前述の LR-115 Type II フィルムと同 じである。LR-115 Type II Stripping B フィルムは片 面に $8 \mathrm{mg} / \mathrm{cm}^{2}$ の $\mathrm{LiBO}_{2}$ を塗布したもので, ${ }^{10} \mathrm{~B},{ }^{6} \mathrm{Li}$ の $(\mathrm{n}, \alpha)$ 反応による $\alpha$ 線を測定して, 間接的に中性子 を検出する目的で作られたものである。

\section{2. 照 射}

LR-115 Type II フィルムの照射には, RaDEF (280 $\mathrm{dps}$ ) 線源の $\mathrm{RaF}$ すなわち ${ }^{210} \mathrm{Po}$ から出る $5.3 \mathrm{MeV}$ の $\alpha$ 線を用い, $20 \mu \mathrm{m}$ 厚のポリカーボネートフィルムを減 速材として, 線源と検出フィルムの間にはさみ, 密着し て照射を行なった。なお，LR-115 Type II Stripping $\mathrm{B}$ フィルムの中性子照射は, UTR-Kinki ${ }^{8)}$, 熱出力 $1 \mathrm{~W}$ で運転し, 原子炬の中央試料孔の中央（熱中性子束密度 $\left.1.4 \times 10^{7} \mathrm{n} / \mathrm{cm}^{2} \cdot \mathrm{s}\right)$ において数秒〜 4 時間照射を行なっ た。またフィルムと同時に金箔を照射し，中性子フルエ ンスを測定した。

\section{3. エッチング}

照射したフィルムは，フィルム上に $\alpha$ 粒子でできた飛 跡を拡大し，放電可能な大きさのエッチピットを得るた め, 未照射フィルムとともに $26 \%$ 水酸化ナトリウム溶 液, $50^{\circ} \mathrm{C}$ または $60^{\circ} \mathrm{C}$ で行なった。

中性子検出用の Stripping B フィルムは, 照射後, 塗布した $\mathrm{LiBO}_{2}$ を水洗し取り除き，上と同じ方法でェ ッチングした。

\section{4. 放電計数}

放電計数は直径 $2.2 \mathrm{~cm}$ の銅の円板陽極とアルミ蒸着 したポリカーボネート（アルミ蒸着膜は $10 \mathrm{~nm}$ 厚）と の間にェッチングしたフィルムを扣き，電極間に高電圧 を印加し，このとき得られる放電パルスを計数器で計数 する。

\section{III 結 果と考 察}

\section{1. 放電計数特性}

LR-115 Type II の種々の開孔電圧での放電計数プラ トー特性を Fig. 1 に示した。これによると，開孔電圧

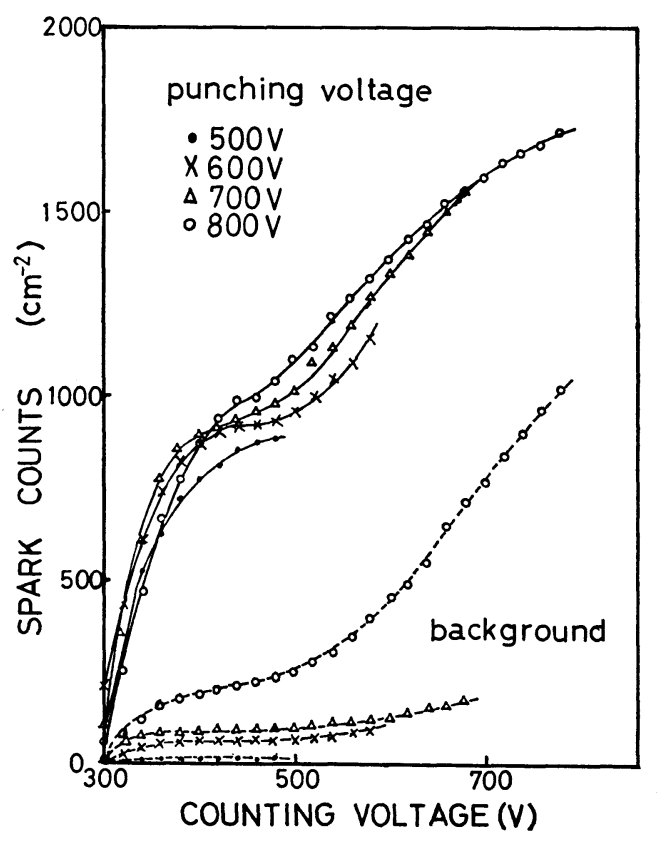

Fig. 1 Spark counts as a function of counting voltages at different punching voltages. 
$600 \mathrm{~V}$ 飞打いて比較的はっきりしたプラト一を示し，ま たこのときのバックグラウンド計数（未照射フィルムを 放電計数したときの值）も少ないので，以後，開孔電圧 $600 \mathrm{~V}$, 計数電圧はプラトー中央の $425 \mathrm{~V}$ に打いて行な った。

Fig. 2, Fig. 3 飞 $26 \%$ 水酸化ナトリウム $50^{\circ} \mathrm{C}$ に打 けるエッチング時間と放電計数值の関係を示した。Fig. 2 は LR-115 Type II と Type II Stripping そつい て，ポリェステルベースより硝酸セルロースフィルムを はがした後エッチングしたもので，両者間に有意の差は なく，最適エッチング時間は 140 分付近であることがわ かる。またフィルムの剥離をエッチングおよび水洗後行 なった場合のエッチング時間と放電計数の関係を Fig. 3 に示した。前者の 140 分に和汀る放電計数値と同じ放電 計数值が得られるェッチング時間は 210 分で前者よりか なり長いが，これはエッチングが片側からのみ行なわれ るためと思われる。同様の場合， $60^{\circ} \mathrm{C}$ に和ける結果を Fig. 4 亿示した。我々は, 前者の場合, $50^{\circ} \mathrm{C}, 26 \%$ 水 酸化ナトリウム溶液に括いて，エッチング時間，140 分 に設定して行なった。このときのエッチピット径は平均 約 $7 \mu \mathrm{m}$ 程度である。

放電計数効率は検出器に入射した $\alpha$ 粒子数に対する放 電計数值の割合で，照射時に線源と検出器の間に挿入す る減速材の種類と厚さによって異る。ここでは減速材に ポリカーボネートシートを使用し，その厚さと放電計数 効率の関係を Fig. 5 亿示した。減速材なしで検出器の 照射を行なった場合，放電計数効率は $5 \%$ であるが， 減速材に $20 \mu \mathrm{m}$ 厚のシートを使用した場合に $44 \%$ と 最高を示したので, 以後, $20 \mu \mathrm{m}$ 厚のポリカーボネート

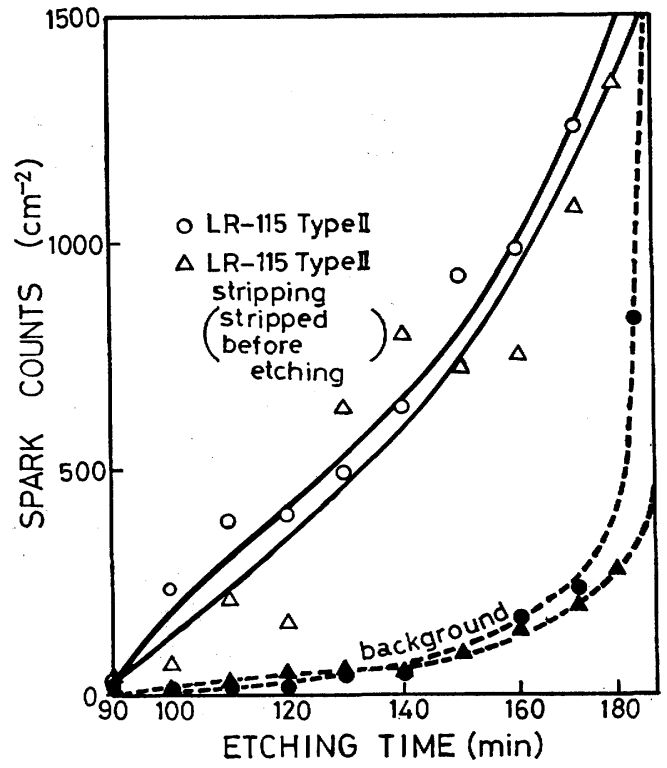

Fig. 2 Spark counts as a function of etching times (LR-115 Stripping film was stripped before etching).

を用いた。この場合，通過した $\alpha$ 線のエネルギーは約 $2.6 \mathrm{MeV}$ であった。

$\alpha$ 線照射量と放電計数值の間の関倸を Fig. 6 亿示し た。これより, 放電計数值 $1,000 / \mathrm{cm}^{2}$ まで比例関係が あり，それ以上では飽和に達した。これは， $\alpha$ 線照射量 が多くなるとアルミ蒸着シートにあいた孔が重なり, 蒸 発孔中のエッチピットの計数が不可能となるためであ る。

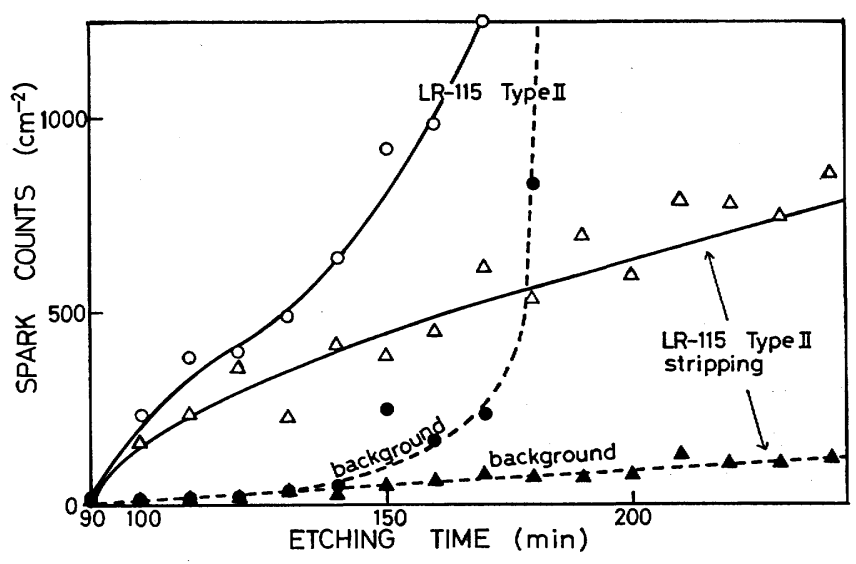

Fig. 3 Spark counts as a function of etching times (LR-115 Stripping film was stripped after etching). 


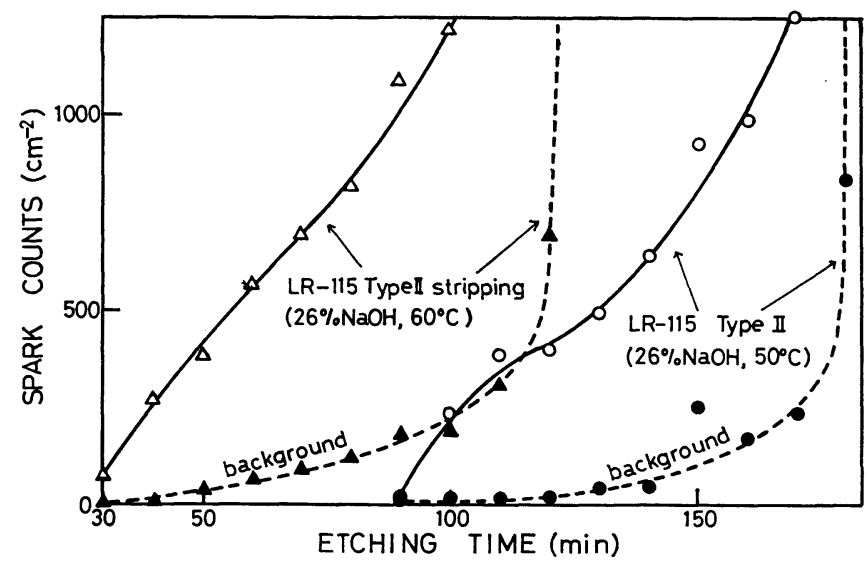

Fig. 4 Spark counts as a function of etching times (LR-115 Stripping film was stripped after etching and etched at different temperature).

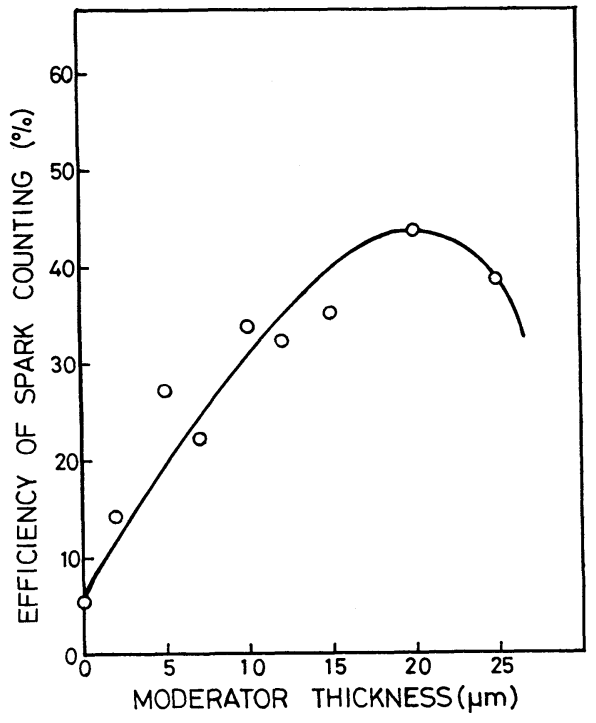

Fig. 5 Efficiencies of spark counting as a function of moderator thicknesses.

\section{2. 中性子フルエンスの測定}

LR-115 Type II Stripping B フィルムを用いて, 中 性子フルエンスを測定し，放電計数值との関係を Fig. 7 に示した。この值はバックグラウンド計数 $200 / \mathrm{cm}^{2}$ を 差引いた值である。な拉バックグラウンド計数の相対標 準偏差は $22 \%$ であり，これを考慮に入れると，放電計 数值で $44 / \mathrm{cm}^{2}$, つまり, 中性子フルェンス $2 \times 10^{8} \mathrm{n} /$ $\mathrm{cm}^{2}$ から測定可能となる。また上限は LR-115 Type II

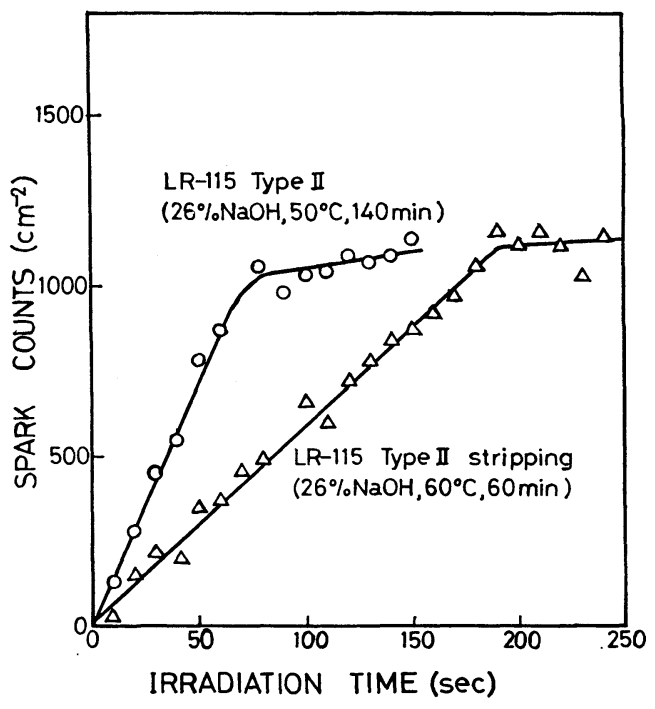

Fig. 6 Spark counts as a function of irradiation times in cellulose nitrate.
Stripping の場合とほほ同様 $1,100 / \mathrm{cm}^{2}$ で, この間に 中性子フルェンスとの間に直線関係が得られた。したが って, 中性子フルエンス約 $2 \times 10^{8} \sim 4 \times 10^{9} \mathrm{n} / \mathrm{cm}^{2}$ の 範囲で測定が可能である。検出感度は $K_{\mathrm{S}}=N / \phi(N$ : 放電計数值 (counts $\left./ \mathrm{cm}^{2}\right), \phi$ : 中性子フルエンス, (n/ $\left.\mathrm{cm}^{2}\right), K_{\mathrm{s}}$ : 感度) より, $K_{\mathrm{S}}=2.7 \times 10^{-7}$ (counts $\left./ \mathrm{n}\right)$ で ある。な打照射場所 (中央照射孔) での Cd 比は約 11 であった。熱中性子を求める場合は速中性子の影響を差 


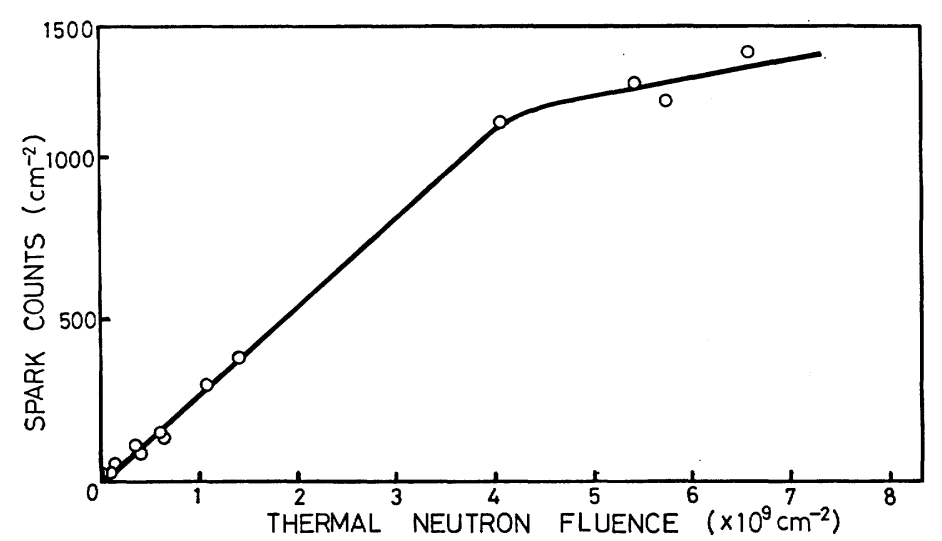

Fig. 7 Relation between spark counts and thermal neutron fluence in cellulose nitrate (LR-115 Stripping B).

引く必要がある。この方法はウランターゲットを用意す る必要がないといら利点がある。

\section{IV ま め}

放電計数法による $\alpha$ 線飛跡検出について, KODAK LR-115 Type II および LR-115 Type II Stripping について放電計数特性を調べ次の結果を得た。

1）エッチング条件は（両者，ポリエステルベースよ り硝酸セルロースをはがしてェッチングを行なったもの について), $26 \%$ 水酸化ナトリウム溶液で, 温度 $50^{\circ} \mathrm{C}$, エッチング時間 140 分が適当であった。なお，ポリエス テルベースに硝酸セルロースを付着したままでエッチン グした場合，前者の 140 分における放電計数值が得られ るエッチング時間は 1.5 倍になった。

2) 放電計数時の開孔電圧および計数電生はそれぞれ $600 \mathrm{~V}, 425 \mathrm{~V}$ にした。

3) ${ }^{210} \mathrm{Po}, \alpha$ 線照射時に使用する減速材のポリカーボ ネートの厚さは, $20 \mu \mathrm{m}$ を用いたものが放電計数効率で 最高であった。なお，この時の $\alpha$ 線のエネルギーは約 $2.6 \mathrm{MeV}$ であった。

5） LR-115 Type II Stripping B を用いて中性子フ ルエンスの測定を行なった結果, $2 \times 10^{8} \sim 4 \times 10^{9} \mathrm{n} / \mathrm{cm}^{2}$ の範囲で測定可能であった。

この研究に協力いただきました, 近畿大学理工学部原 子炬工学科卒業生, 磯部泰久氏, 畑田博一氏, 保科重徳 氏，中野浩彰氏，広兼千幸氏に感謝します。また実験材
料（LR-115）の貸与および助言をいただきました京都大 学原子炉実験所, 鶴田隆雄氏, また, LR-115 Stripping フィルムについて技術上の助言をいただきをした KODAK PATHÉ 社の LECÁRT 氏にも感謝いたしま †。

\section{参考文 献}

1) W.G. Cross and L. Tommasino; Rad. Eff., 5, 85 (1970).

2) D.R. Johnson, R.H. BoyetT and K. BeCKeR; Health Phys., 18, 424 (1970).

3) K. BECKeR, M. ABD-EL RAZEK; ORNL-TM4460 (1974).

4) K. BeCKer, M. ABD-El RAZEK; Nucl. Instrum. Methods, 124, 557 (1975).

5) P.B. Hahn, M.A. Wechter and A.F. VoigT; Nucl. Instrum. Methods, 123, 111 (1975).

6) 御座精二, 鶴田隆雄, 桂山幸典, 森嶋彌重, 河合 廣; 日本保健物理学会第 13 回発表会要旨集, p. 12 (1978).

7) 丹羽健夫, 森嶋彌重, 古賀妙子, 河合 廣, 保科 重徳, 西脇 安; 日本保健物理学会第 12 回発表 会要旨集, p. 13 (1975).

8）森嶋儞重，古賀妙子，丹羽健夫，本田嘉秀，河合 廣, 長野文彦, 西脇 安; 保健物理, 10, 141 (1975). 